\title{
Acceptability and Antioxidant Activity Level of Shredded Banana Flower- Chicken Meat
}

\author{
Novidiyanto*1,2 ${ }^{*}$ Ori Pertami Enardi ${ }^{1,2}$, Ade Devriany ${ }^{1,2}$, Auronita Puspa Pratiwi $^{1}$, Musrifa Airuni ${ }^{3}$
}

\begin{abstract}
Background: Data Riskesdas 2013 shows that the average amount portion of vegetable consumption in people aged 10 years or older is only 0.5 portions while the vegetable consumption category is said to be "sufficient" is at least 5 portions per day for 7 days a week. Banana blossom is a vegetable and commonly found in Bangka Belitung Islands Province. Banana blossom processing as a source of vegetables rich in antioxidant compounds and chicken meat as a source of animal protein, needs to be done by processing into shredded banana blossom-chicken meat.

Objectives: To determine the acceptability and antioxidant activity level of shredded banana blossom-chicken meat.

Methods: This research was experimental. Variation substitution of banana flower and chicken meat as a main ingredient of shredded, made using 3 formulations, each of which is Formula 1 (F1) 75\%: 25\%, Formula 2 (F2) 50\%: 50\%, and Formula 3 (F3) 25\%: 75\%. Furthermore, the acceptance of taste, colour, aroma, texture, overall, and antioxidant activity level of shredded banana blossom-chicken meat.

Results: There was a significant difference in the acceptance of the colours and overall, of shredded F1, F2 and F3 ( $p<0.05)$, while aroma, taste and texture of the shredded F1, F2 and F3 were not significant ( $p>0.05)$. Shredded F3 (banana blossom 25\%: chicken meat 75\%) is most preferred based on the parameters of colour, aroma, taste, texture and overall, and has the highest antioxidant activity value are $53.74 \%$.

Conclusions: Shredded banana blossom-chicken meat has a good acceptability and has a high antioxidant activity level.
\end{abstract}

Keywords: Shredded, banana flower, acceptability, antioxidant

\author{
*Correspondence: \\ novidi2011@gmail.com \\ 1 Pusat Unggulan IPTEK-Poltekkes Kemenkes Pangkalpinang Komplek Perkantoran Pemprov Kep. Bangka Belitung- \\ Pangkalpinang \\ 2 Jurusan Gizi Poltekkes Kemenkes Pangkalpinang Komplek Perkantoran Pemprov Kep. Bangka Belitung-Pangkalpinang \\ ${ }^{3}$ Dinas Pertanian dan Pangan Kabupaten Bangka BaratKomplek Perkantoran Pemda Kabupaten Bangka Barat-Mentok
}

\section{INTRODUCTION}

Basic Health Research Data (Riskesdas) in 2013 shows that the average portion of fruit and vegetable consumption among people aged 10 years or more in the Bangka Belitung Islands Province is in the under category1. The category of fruit and vegetable consumption is said to be sufficient if people consume at least 5 servings of vegetables and or fruit per day for 7 days a week. The average number of portions of vegetable consumption per day in Bangka Belitung Islands Province is only 0.9 portions.

The low number of servings of vegetables and fruit consumption can cause health problems such as obesity, cancer, stroke and diabetes mellitus. Conversely, several studies have shown that consuming adequate amounts of vegetables and fruit can prevent chronic diseases such as heart disease, cancer2,3 and can increase physical activity4. Vegetables and fruit contain nutrients, fiber and are low in calories. Consumption of vegetables and fruit with high density content can also have a good impact on energy balance so that you can lose weight5.
Apart from containing nutrients, vegetables and fruit also contain antioxidant compounds. The amount of ability of a food ingredient to ward off free radicals can be known through the value of antioxidant capacity6. The imbalance of the antioxidant system and free radical compounds in the body causes a person to experience oxidative stress, where the body will oxidize polyunsaturated fatty acids (PUFAs, Poly Unsaturated Fatty Acids), proteins, DNA and sterols in the body. Antioxidant compounds can help maintain the balance of oxidative stress in the body, thereby reducing the incidence of cardiovascular disease and cancer.

The antioxidant capacity of vegetables and fruit has been tested through studies involving several people as research subjects. Antioxidant compounds such as flavonoids are known to have a higher antioxidant capacity than vitamins $C$ and $E$. Research on providing vegetable and fruit extract supplements for 4 weeks to 15 people as research subjects, has been shown to reduce plasma lipid peroxidase levels from $16.85 \mu \mathrm{mol} / \mathrm{L}$ to 3,3 $\mu \mathrm{mol} / \mathrm{L} 7$. Another study explains that consumption of green bean sprouts can also reduce levels of malondealdehyde (MDA) plasma and liver tissue in rats 
fed a high-fat diet8. Malondealdehyde is an aldehyde compound that is formed from the process of lipid peroxidation in unsaturated fatty acids9. High levels of malondealdehyde in blood plasma, indicate that a person's body is experiencing an imbalance in antioxidant levels in the body.

Banana heart is often found in Indonesia, especially in the Province of Bangka Belitung Islands. Banana heart is one type of vegetable that comes from the banana plant. In $100 \mathrm{~g}$, fresh banana blossoms contain 32 calories of energy, $7.1 \mathrm{~g}$ carbohydrates, $1.2 \mathrm{~g}$ protein, $0.3 \mathrm{~g}$ fat, $3.2 \mathrm{~g}$ dietary fiber, $170 \mu \mathrm{g}$ total carotene content and $10 \mathrm{mg} 10$ vitamin $\mathrm{C}$. The dietary fiber content of the banana heart of $5.7 \mathrm{~g}$ is known to maintain a person's health, reduce blood cholesterol levels and prevent obesity ${ }^{11}$.

Apart from nutrients, banana flower is known to contain antioxidant compounds such as phenolic compounds and flavonoids. The antioxidant capacity, phenol content and flavonoids of several types of banana flower in Malaysia have been studied before. Nipah banana heart (another name for Nipah banana heart in Indonesia is Kepok banana heart) contains phenolic compounds of $46.06 \mathrm{mg}$ of GAE / g, flavonoid content of $27.49 \mathrm{mg}$ of QE / $\mathrm{g}$ and DPPH antioxidant activity of 16, 80 umole of Trolox / g12. Another study showed that the banana heart (Musa sp) of the Kacha cultivar contained $11.94 \mathrm{mg}$ of polyphenols and $0.174 \mathrm{~g}^{13}$ of flavonoids. Polyphenol components in a food ingredient can counteract free radicals by inactivating free radical lipids or preventing hydroperoxide components from becoming free radical compounds14. A study revealed that banana flower can be used as a diet for various diseases including diabetes. Giving a banana heart diet to diabetic rats, can significantly reduce the blood glucose levels of the rats ${ }^{11}$. One of the efforts to increase the consumption of banana blossoms in the community is through processing the banana blossoms into shredded. In order for the banana heart to be processed into shredded floss to be well accepted by the community and have a high antioxidant functional value, then shredded banana flower needs to be substituted with chicken meat. Chicken meat is a source of animal protein which is important for the fulfillment of community nutrition. Banana heart and chicken meat are very easy to obtain in the community. The availability of chicken meat in the community can be found in traditional and modern markets. Based on the description above, this research was conducted to determine the acceptability of color, taste, aroma and overall parameters as well as the value of antioxidant activity of banana floss and chicken meat.

\section{METHODS}

The design of this research is experimental. The design design used a completely randomized design (CRD) with 1 factor, namely the formulation factor, which consisted of variations in the composition of banana heart and chicken meat as the main basic ingredients for making shredded. The composition of banana heart and chicken meat in shredded formula 1 (F1) is $75 \%$ and $25 \%$, Formula 2 (F2) $50 \%$ and $50 \%$, and formula 3 (F3) $25 \%$ and $75 \%$. Each formulation was made 2 repetitions. The formulation for making shredded banana heart-chicken meat can be seen in Table 1 .

Table 1. Formulation of shredded banana flower - chicken meat

\begin{tabular}{llll}
\hline Ingredients & Formula 1 (F1) & Formula 2 (F2) & Formula 3 (F3) \\
\hline Banana heart (g) & 187.5 & 125 & 62.5 \\
Chicken meat (with) & 62.5 & 125 & 187.5 \\
Shallot (\&) & 18.75 & 18.75 & 18.75 \\
Garlic (g) & 3.75 & 3.75 & 3.75 \\
Coriander Powder (g) & 6 & 6.24 & 6.24 \\
Galangal (g) & 25 & 25 & 25 \\
Bay leaves (g) & 2 & 2 & 2 \\
Lemongrass (g) & 5 & 5 & 5 \\
Sugar (g) & 37.5 & 37.5 & 37.5 \\
Salt (g) & 2.5 & 2.5 & 2.5 \\
Thick coconut milk (mL) & 6.5 & 6.5 & 6.5 \\
Cooking oil (L) & 0.5 & 0.5 & 0.5 \\
\hline
\end{tabular}

The research was conducted at the CulinaryDietetic-Food Laboratory of the Department of Nutrition, Health Polytechnic of the Ministry of Health, Pangkalpinang and the Center for Food and Nutrition Studies (PSPG) UGM Yogyakarta. This research was conducted from February 2018 to September 2018. All samples were selected using purposive sampling method.

The acceptance test was carried out by trained panelists15, who were 30 students of the DIII Nutrition Study Program at the Ministry of Health Pangkalpinang's Health Polytechnic Study Program. The test for the acceptance of the shredded banana and chicken meat included taste, aroma, color, texture and overall parameters. The acceptance test used the hedonic test.
The acceptance test scale used is 1 to 5 , namely $1=$ very dislike, 2 = dislike, 3 = ordinary, $4=$ like, $5=$ very like it. The criteria for panelists are 17-19 years old, not smoking, in good health, willing to be a panelist, and understand the theory of acceptance testing.

Measurement of the antioxidant activity value of shredded banana and chicken meat was carried out using the DPPH radical scavenging method16. The steps for testing shredded antioxidant activity are as follows: 1 gram of shredded sample is dissolved with $1 \mathrm{~mL}$ of methanol solution for 2 hours. Then, as much as $1 \mathrm{~mL}$ of the extract solution is put into a test tube and add $1 \mathrm{~mL}$ of the 1,1, 2,2 - Diphenyl Picryl Hydrazyl (DPPH) solution. Incubate in a dark room for 30 minutes. Furthermore, 
dilution is carried out by adding methanol solution up to $5 \mathrm{~mL}$. The control used as a blank was made by adding 1 $\mathrm{mL}$ of DPPH solution with $4 \mathrm{~mL}$ of ethanol. The absorbance was measured using a spectrophotometer at a wavelength of $515 \mathrm{~nm}$. Calculation of total antioxidant activity $(\%)=[(A B-A A) / A B] \times 100 \% . A A=$ absorbance of the test sample after incubation for 30 minutes, and $A B=$ absorbance of the control.

The data processing of the acceptance test results and the value of antioxidant activity was carried out using quantitative analysis. The panelists' acceptance of color, aroma, taste, texture and overall parameters obtained was then tested for normality using the Kolmogorof-Smirnof test. After the normality test, the difference test was carried out using the one-way ANOVA parametric statistical test and the Post hoc Tukey test (if the data were normally distributed), and the KruskalWallis non-parametric statistical test and the MannWhitney test were carried out (if the data were not normally distributed). If the $p$ value $<0.05$, there is a significant difference, but if the $p$ value $>0.05$ then there is no significant difference between the formulations for making shredded shredded products. This research has received an Ethical Clearance from the Ethical Commission for Health Polytechnic of the Ministry of Health Pangkalpinang Number 14 / EC / KEPK-PKP / V / 2018 on May 22, 2018.

\section{Tools and Materials}

The tools used for the manufacture of shredded banana-chicken meat are pot, stove, basin, spoon, fork, knife, bowl, blender, shredded press, filter, scale and press. The tools for the acceptance test are ballpoint pens, plastic plates and a favorite level test form. Tools for analyzing antioxidant activity are measuring flasks, test tubes, vortices, incubators and water baths.

The main ingredients for making shredded shredded are Kepok banana heart and chicken meat, while the additional ingredients used are shallots, garlic, coriander powder, galangal, bay leaves, lemongrass, granulated sugar, salt, flavorings, coconut milk, and cooking oil. The main ingredients and additional ingredients are obtained from the Air Itam Market in Pangkalpinang City. The materials used to test the value of antioxidant activity, namely methanol solution, 1,1, 2,2-Diphenyl Picryl Hydrazyl (DPPH) solution, ethanol solution, and distilled water, were obtained from the Nutrition Laboratory of the Center for Food and Nutrition Studies (PSPG) UGM Yogyakarta.

\section{Instruction}

The working method of making shredded banana-chicken meat is as follows: banana and chicken meat are sorted and then washed clean. After that, the banana heart and chicken meat are cut to a size of $5 \mathrm{~cm} \mathrm{x}$ $5 \mathrm{~cm} \times 5 \mathrm{~cm}$, then cooked by boiling, adding salt, lemongrass and bay leaves until cooked, then drain. Banana heart and chicken that have been cooked are then pounded and shredded and mixed evenly with the spices that have been mashed before. The spices are coriander powder, salt, sugar, flavorings, shallots, garlic, galangal and coconut milk. After mixing evenly, the dough is left to stand for 10 minutes. After settling, the shredded dough is fried using hot cooking oil then drained. After being drained, the shredded is then pressed and then decomposed.

\section{RESULTS AND DISCUSSIONS}

The acceptability test of banana heart-chicken meat shredded includes parameters of color, aroma, taste, texture and overall, through hedonic test. The panelists in the study were trained panelists totaling 30 people. The assessment is carried out using a score of 1 to 5 , namely very dislike (1), dislike (2), normal (3), like (4) and very like (5). Shredded banana heart and chicken meat results of the study can be seen in Figure 1 .

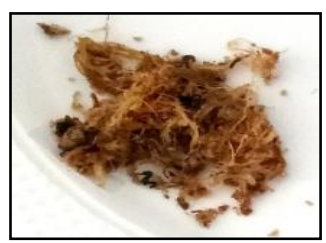

Shredded Formulation 1

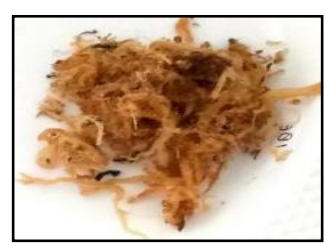

Shredded Formulation 2

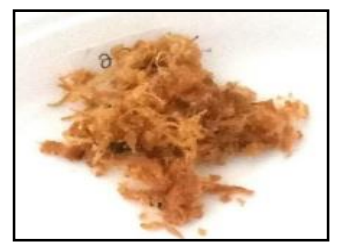

Shredded Formulation 3

Figure 1. Shredded banana heart-chicken meat

After the test data for the acceptability of the shredded banana and chicken meat were obtained, the next step was to test the normality and distribution of the data using the Kolmogorof-Smirnof test. The KolmogorofSmirnof test results showed that the distribution of acceptance data was not normal $(p<0.05)$. Based on this, data testing was continued with the Kruskal Wallis test.

\section{Shredded Color Acceptance}

Shredded color acceptance is determined using the panelist's sense of sight. The quality of a food product can be determined by its color17. The results of the shredded acceptance test using the hedonic test based on the number of panelists, can be seen in Figure 2 . 


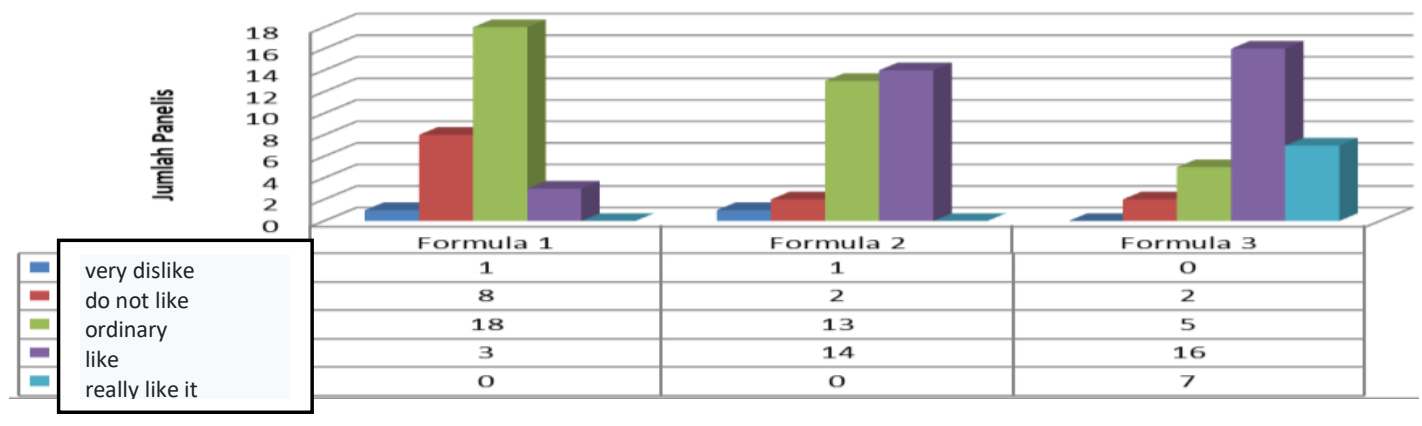

Figure 2. Panelists' acceptance of the color of shredded banana-chicken meat

The results of statistical tests on the acceptability of shredded color using the Kruskall Wallis test obtained $p$ value $=0.000$. The test results indicate that there are significant color differences in shredded F1, F2 and F3. Based on Figure 2, it is known that the shredded F1 color was liked by 3 panelists, 14 people liked the shredded $F 2$ color and the F3 shredded color was liked by the panelists as many as 23 people ( 16 people liked F3 shredded and 7 people very liked). Thus, the shredded color F3 was mostly favored by panelists. Shredded F3 has a bright brown color, shredded F2 has a brown color and shredded F1 is dark brown.

The more banana flower composition and the less chicken meat substituted in each shredded formula; the resulting shredded color will be browner. Conversely, the less banana blossoms and more chicken meat were substituted, the resulting shredded color would be light brown. The difference in shredded color in each formulation is thought to be caused by differences in the number of banana hearts and substituted chicken meat.

Banana heart has a brownish red color while chicken meat has a pale white color18. The red color of the banana heart is caused by the presence of high anthocyanin content in the outer layer of the Kepok banana heart. The antioxidant content of banana flower is $32.14 \mathrm{mg} / 100 \mathrm{~g}$. Antiocyanin is a phenolic compound that belongs to the flavonoid group. Anthocyanins in a food ingredient have a combined effect of blue-violet and orange colors on fruits and flowers, are soluble in water and have a high color intensity19. Anthocyanins play an important role for human health, namely to prevent various degenerative diseases. Apart from the anthocyanin content of banana flower, the difference in shredded color in the three formulas is also caused by the mailard reaction during the cooking process. The mailard reaction is a non-enzymatic reaction that occurs between reducing sugars and proteins forming a brown compound 20 .

\section{Acceptance of Shredded Aroma}

The results of the statistical test of the acceptability of the aroma of shredded banana and chicken meat using the Kruskall Wallis test obtained $p$ value $=0.212$. The test results indicated that different variations of banana heart and chicken meat substitutions in each formula did not show a significant difference in the acceptability of shredded aroma. However, if we look at the average results of the assessment based on the number of panelists, the F3 shredded shredded F3 was mostly favored by the panelists.

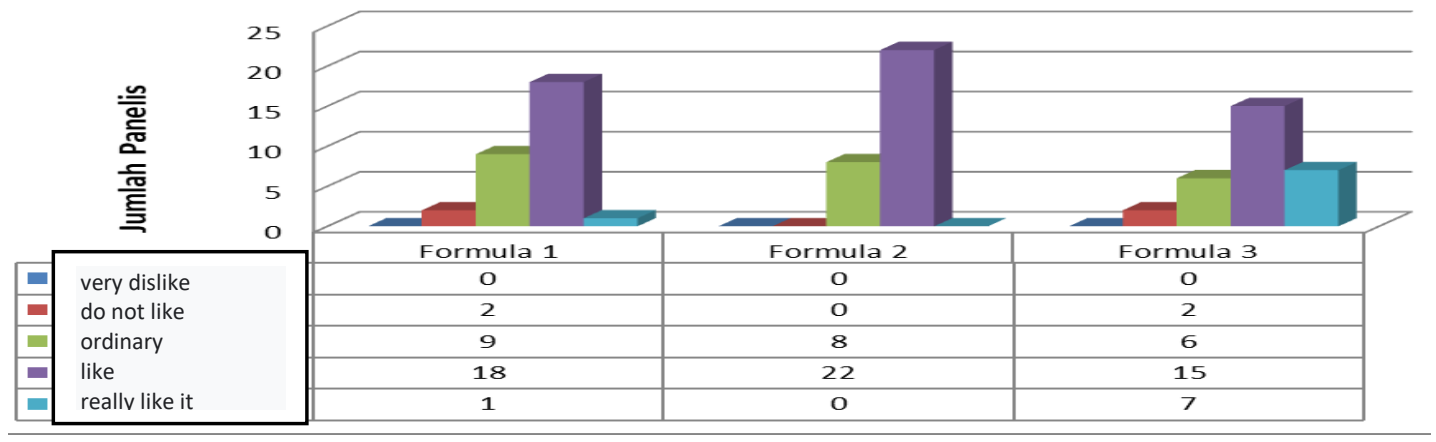

Picture 3. Panelists' receptivity to the aroma of shredded banana-chicken meat

Based on Figure 3, it is known that the aroma of shredded F1 was liked by 19 people (18 people liked F1 shredded and 1 person really liked) while 22 people liked shredded F2 and F3 shredded aroma (F3 shredded 15 people liked and 7 people very liked. ). Shredded made from banana heart and chicken meat has a distinctive aroma, which is a combination of the aroma of chicken meat and spices. The distinctive aroma of spices dominates the shredded shredded produced 21.

There is no difference in the aroma of shredded floss in the three formulations due to the same amount of additional ingredients used, such as spices and coconut 
milk. The spices used in the manufacture of shredded floss are coriander, shallots and garlic21. The food that is brought to the mouth is felt by the senses of taste and smell which is then accepted and interpreted by the brain. The smell of food that is in the mouth will be captured by the sense of smell through the channel that connects the mouth and nose22.

Apart from seasoning, another factor that affects the aroma of shredded is the cooking process. The method of cooking shredded in the three formulas is the same, namely cooking using hot oil. During the cooking process, the shredded will experience a mailard20 reaction. The mailard reaction produces aldehydes from the reaction of free amine groups of amino acids with reducing sugars, with the degradation of fats (oxidation and hydrolysis) to produce aldehydes, lactones, ketones, alcohols and ethers.

\section{Acceptance of Shredded Taste}

The acceptance of the floss of banana heart and chicken meat based on the number of panelists can be seen in Figure 4

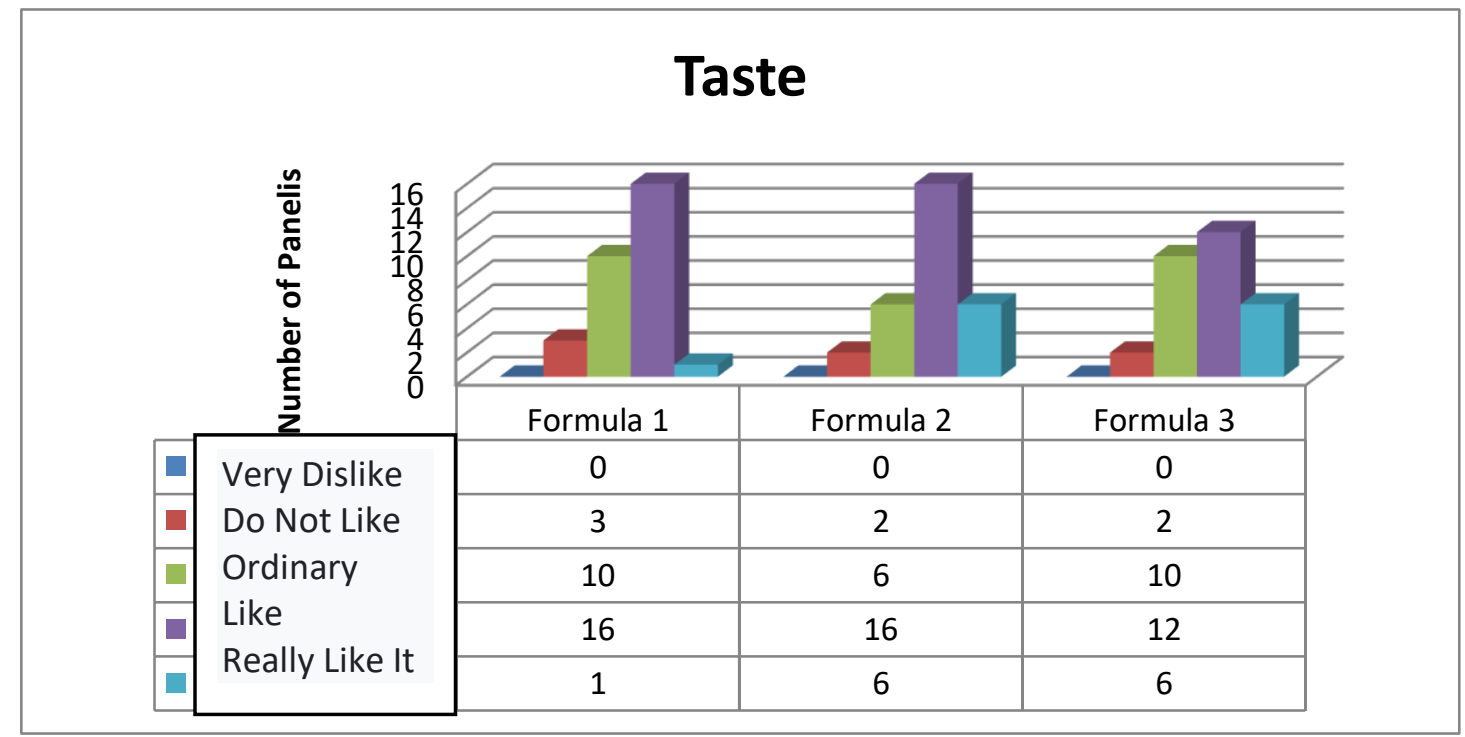

Figure 4. Panelists' receptivity to the floss of banana heart-chicken meat

From Figure 4, it is known that the floss F1 was liked by the panelists as many as 17 people (16 people liked the $\mathrm{F} 1$ shredded and 1 person really liked it) and the floss F2 was liked by the panelists as many as 22 people (16 people liked the F2 shredded floss and 16 people really liked it. as many as 6 people). The taste of the F3 shredded was liked by the panelists as many as 18 people (the F3 shredded was liked by the panelists as many as 12 people and very liked by 6 people)

The results of statistical tests showed that the panelists' acceptance of the taste of shredded banana heart and chicken meat F1, F2 and F3 did not differ significantly $(p$ value $=0.201)$. The differences in the composition of the banana heart and chicken meat did not affect the flavors of F1, F2, and F3. The absence of differences in floss flavors $F 1, F 2$ and $F 3$ is caused by several factors. The first factor is the composition of the added sugar and salt added to the shredded production is the same. The resulting flossy taste is sweet and savory. The sugar and salt added to the three formulations are 35.5 grams and 2.5 grams, respectively. Sugar serves to provide flavor and strengthen taste ${ }^{21}$.

The second factor is the absorption of the shredded dough before cooking. In the process of making shredded, banana flower and chicken meat as the main ingredients are mixed with the spices until evenly distributed, then let stand for a few minutes. This process aims to infuse the spices into the main ingredients, namely banana heart and chicken meat, so that the shredded product is produced with the quality of the shredded flavor that the panelists like.

\section{Acceptability of Shredded Texture}

The panelists received the shredded texture through hand touch. From the results of statistical tests, it is known that the differences in the composition of the composition of banana heart and chicken meat substitution showed no significant difference $(p$ value $=$ 0.84 ) on the texture of the shredded. The texture of the shredded F1 was liked by the panelists as many as 11 people (10 people liked the shredded F1 texture and 1 person really liked it) and the shredded F1 texture was liked by the panelists as many as 15 people. The shredded texture $\mathrm{F} 3$ was liked by the panelists as many as 20 people (the shredded texture $\mathrm{F} 3$ was liked by 17 people and very liked by 3 people). Based on this, even though there were differences in the composition of the banana heart and the substituted chicken meat, the shredded texture of F1, $\mathrm{F} 2$ and $\mathrm{F} 3$ was still mostly favored by the panelists. 


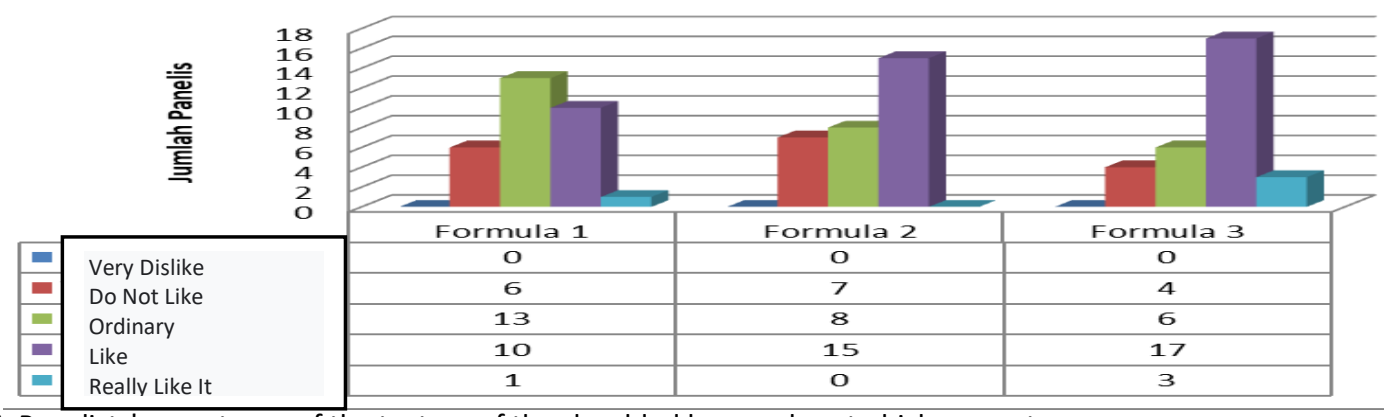

Figure 5. Panelists' acceptance of the texture of the shredded banana heart-chicken meat

Most of the panelists liked the shredded texture of the three formulations. Panelists considered that the resulting shredded texture was the same as the shredded texture on the market in general. The more the composition of the banana heart, the resulting shredded balky and fine fiber, while the more the composition of the chicken meat, the resulting shredded texture was shaped like a balky (balky) and coarse fiber21. Despite the difference in texture, the shredded F1, F2 and F3 were still liked by the panelists.

The texture of the shredded is influenced by the texture of the main ingredients, salt, and the processing 21. Banana heart has a soft texture and fine fiber, while the chicken meat has a coarse, chewy and tender fibrous texture18. Apart from the texture of the main ingredients, another factor that affects the texture of the shredded is the use of salt in the manufacture of shredded. Salt can help extract the myofibrillar protein of meat. Chicken protein extract acts as an adhesive to bind chicken meat particles to form the desired shredded texture22.
Another factor that affects is the processing process. The processing that affects the most is the process of shredding and decomposing after the shredded is cooked using hot oil. The shredding process produces the texture of banana heart and chicken meat which is uniform and smooth. After that, the hot oil cooking process will produce a dense and clumpy shredded texture. Therefore, in this study, the shredded decomposition process was carried out by shredding it manually using a fork. After decomposing, the shredded texture becomes coarse fibrous, and has a uniform size ${ }^{21}$.

\section{Overall Abon Acceptance}

The panelists' acceptance of the shredded banana heart and chicken meat F1, F2 and F3 as a whole showed that there was a significant difference $(p$ value $=$ 0.015 ) between shredded F1, F2 and F3. Assessment of the overall acceptance of shredded based on the number of panelists can be seen in Figure 6 .

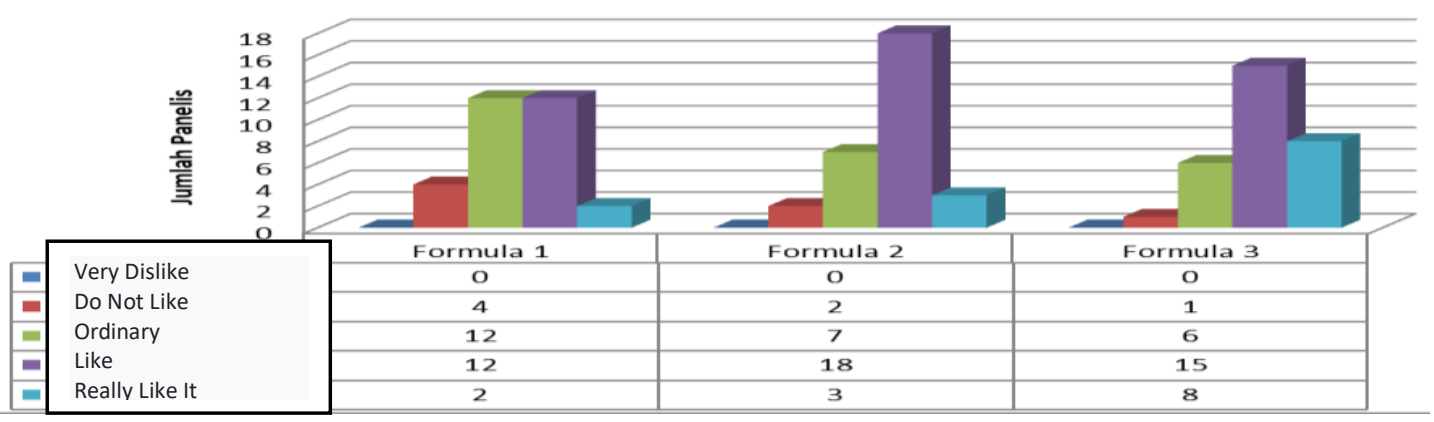

Figure 6 . The overall acceptance of the panelists on the shredded banana heart-chicken meat

From Figure 6, it is known that the overall acceptance of floss increases with the increase in the amount of chicken meat added to each formulation. Panelists who like shredded F1 are 14 people (shredded F1 is liked by 12 people and 2 people are very liked), shredded F2 is liked by panelists as many as 21 people (shredded F2 is liked by panelists is 18 people and is very liked by 3 people) and shredded F3 23 people liked the panelists ( 15 people liked the shredded F3 and 8 people liked it very much). Panelists gave an acceptance rating on the overall parameters based on a combination of factors of color appearance, aroma, taste, and shredded texture. The overall acceptance attribute is an important thing to do because it shows consumer acceptance of the quality of shredded products ${ }^{21}$

The acceptability of a food product is influenced by many factors, namely individual factors, the food factor itself or the environment where the food is located. In this study, the panelists who performed the shredded hedonic test were trained panelists. The choice of panelist category is one of the important factors in conducting sensory analysis. The sensory analysis carried out is an interpretation of product attributes through the five human senses, namely the senses of sight, smell, taste, touch and hearing ${ }^{15}$. 


\section{Value of Shredded Antioxidant Activity}

In food, antioxidant compounds can inhibit, delay or prevent the oxidation of fat or other easily oxidized compounds. Compounds that can be easily oxidized will cause food damage, giving rise to a rancid (rancid) odor 6. Parameters that can describe the percentage of a food ingredient's ability to inhibit free radicals are by measuring the value of antioxidant activity. The antioxidant activity value of shredded banana flower and chicken meat was carried out using the DPPH (1-1diphenyl-2-picrylhydrazyl) method. Measurement of antioxidant activity using the DPPH method shows the ability of antioxidant substances to neutralize free radicals in vitro ${ }^{23}$.

Based on the results of statistical tests, it is known that the antioxidant activity of shredded F1, F2 and $F 3$ is not significantly different ( $p$ value $=0.10$ ). Although not significantly different, the differences in the composition of banana heart and chicken meat substituted for shredded F1, F2 and F3 had different antioxidant activities. The antioxidant activity of shredded F1, F2 and F3 is shown in Table 2. The highest antioxidant activity was shredded $\mathrm{F} 3$ at $53.74 \%$, while the lowest antioxidant activity was shredded F1 at $42.50 \%$.

Table 2. Value of Antioxidant Activity of Banana Heart Shredded and Chicken Meat

\begin{tabular}{lcc}
\hline \multirow{2}{*}{ Treatment } & Antioxidant Activity Value (\%) & P value \\
\hline Abon F1 & 42.50 & 0.10 \\
Abon F2 & 46.95 & \\
Abon F3 & 53.74 & \\
\hline
\end{tabular}

Information

Shredded F1 is shredded with a composition of $75 \%$ banana heart and $25 \%$ chicken meat

Shredded F2 is shredded with a composition of $50 \%$ banana heart and $50 \%$ chicken meat

Shredded F3 is shredded with a composition of $25 \%$ banana heart and $75 \%$ chicken meat

The results showed that the F3 shredded with $25 \%$ banana heart substitution and $75 \%$ chicken meat, had an antioxidant activity of $53.74 \%$, the highest compared to shredded $\mathrm{F} 2$ and $\mathrm{F} 1$, namely $46.95 \%$ and $42.50 \%$, respectively. The difference in antioxidant activity in the three formulas is thought to be caused by a decrease in the antioxidant compound content in shredded.

The decrease in the content of antioxidant compounds in shredded is caused by several factors. The first factor is the heating process. During the processing process, the ingredients for making shredded go through two heating processes. The first heating is the process of boiling the banana heart-chicken meat and the second heating is the process of frying the shredded dough using hot oil until cooked.

Cooking shredded using hot oil is done using the deep frying method21. During the heating process, the antioxidant compounds in the banana heart and spices, such as phenol compounds and flavonoids, will be damaged. This is supported by several previous studies. Research shows that the antioxidant activity of raw vegetables decreases when the vegetables are sautéed 24 and it is known that the antioxidant activity of chicken nuggets with rice bran substitution decreases after the nuggets are fried until cooked ${ }^{25}$.

The second factor is how long it takes to cook shredded. The difference in the cooking time of shredded floss in each formulation is influenced by the moisture content of the dough for each formulation. The more the banana flower composition, the longer the cooking time for the shredded. Shredded F1 with more banana flower composition compared to shredded F2 and F3, has a higher water content. Before boiling, the water content in the banana heart was $90.2 \mathrm{~g} / 100 \mathrm{~g}$ and the water content of the chicken meat was 55.9 / 100 g10. The water content of the banana flower will increase during the boiling process. With high water content and longer cooking time, it is suspected that the content of phenol and flavonoid compounds will be damaged by heating19, causing the antioxidant activity value of shredded F1 to be lower than the antioxidant activity values of shredded F2 and shredded F3. Banana heart contains antioxidant activity values derived from phenolic compounds and flavonoids14. Polyphenol components in food, can ward off free radicals by activating free radical lipid reactions or preventing hydroperoxide components from becoming free radical compounds ${ }^{14}$.

\section{CONCLUSION}

The difference in the composition of the banana heart and chicken meat in the shredded Formula 1, Formula 2 and Formula 3 has a significant effect on the panelists' acceptance of the color and parameters of the shredded as a whole, but does not significantly affect the taste, aroma and texture of the shredded shredded. The banana-chicken heart shredded has the color, taste, aroma and texture that most of the panelists like. Panelists gave likes and likes on the three shredded formulations.

Apart from having received power by the panelists, shredded banana-chicken meat has a high antioxidant activity value. Shredded banana with less chicken meat (shredded F3), had the highest antioxidant activity value of $53.74 \%$, while shredded banana with more banana flower composition than chicken (shredded F1) had the highest antioxidant activity value. low, namely 42.50\%. Shredded with the same heart and chicken meat composition (shredded F2), had an activity value of 46.95\% (shredded F2). Antioxidant compounds contained in shredded can ward off free radicals, causing beneficial effects on health. 


\section{ACKNOWLEDGEMENT}

The author would like to express his deepest gratitude to the Poltekkes of the Ministry of Health, Pangkalpinang, who has provided research funds for the author as a researcher in the form of the 2018 Beginner Lecturer Research (PDP) scheme so that this research can be carried out and completed on time until the publication stage of scientific papers.

\section{REFERENCE}

1. Badan Penelitian dan Pengembangan Kesehatan. Laporan Hasil Riset Kesehatan Dasar (Riskesdas) Indonesia tahun 2013. Riset Kesehatan Dasar 2013 (Kemenkes, 2013).

2. Mary Ann S. Van Duyn, E. P. Overview of the health benefits of fruit and vegetable concumption for the dietetics professional: Selected literature. Journal of the American Dietetic Association vol. 100 1025-1030 (2000).

3. Schroder, K. E. E. Effects of fruit consumption on body mass index and weight loss in a sample of overweight and obese dieters enrolled in a weight-loss intervention trial. Nutrition 26, 727734 (2010)

4. Wise, J. A., Morin, R. J., Sanderson, R. \& Blum, K. Changes in plasma carotenoid, alphatocopherol, and lipid peroxide levels in response to supplementation with concentrated fruit and vegetable extracts: a pilot study. Top. Catal. 57, 445-461 (1996).

5. Bazzano, L. A., Serdula, M. K. \& Liu, S. Dietary intake of fruits and vegetables and risk of cardiovascular disease. Curr. Atheroscler. Rep. 5, 492-499 (2003).

6. Santoso, U. Antioksidan Pangan. (UGM Press, 2016).

7. Bhaskar, J. J., Salimath, P. V. \& Nandini, C. D. Stimulation of glucose uptake by Musa sp. (cv. elakki bale) flower and pseudostem extracts in Ehrlich ascites tumor cells. J. Sci. Food Agric. 91, 1482-1487 (2011).

8. Novidiyanto, N., Arta, F. \& Lily Arsanti, L. Pengaruh pemberian kecambah kacang hijau (Phaseolus radiatus (L.)) terhadap kadar malondealdehid (MDA) plasma dan jaringan hati tikus Sprague Dawleyyang diberi pakan lemak tinggi. J. Gizi Klin. Indones. (2019).

9. Yang, R.-L., Shi, Y.-H., Hao, G., Li, W. \& Le, G.-W. Increasing oxidative stress with progressive hyperlipidemia in human: relation between malondialdehyde and atherogenic index. J. Clin. Biochem. Nutr. 43, 154-158 (2008).

10. Kemenkes, R. I. Tabel Komposisi Pangan Indonesia. Jakarta Kemenkes RI (2017).

11. Velioglu, Y. S., Mazza, G., Gao, L. \& Oomah, B. D. Antioxidant Activity and Total Phenolics in Selected Fruits, Vegetables, and Grain Products. J. Agric. Food Chem. 46, 4113-4117 (1998).

12. Marikkar, J. M. N., Tan, S. J., Salleh, A., Azrina, A. \& Shukri, M. A. M. Evaluation of banana (Musa sp.) flowers of selected varieties for their antioxidative and anti-hyperglycemic potentials. Int. Food Res. J. 23, 1988-1995 (2016).

13. China, R. et al. In vitro Antioxidant Activity of Different Cultivars of Banana Flower (Musa paradicicus L.) Extracts Available in India. J. Food Sci. 76, 1292-1299 (2011).

14. Krishnan, A. \& Sinija, V. R. Proximate Composition and Antioxidant Activity of Banana Blossom of Two Cultivars in India. Int. J. Agric. Food Sci. Technol. 7, 13-22 (2016).

15. Setyaningsih, D., Apriyantono, A. \& Sari, M. P. Analisis Sensori untuk Industri Pangan dan Argo. (PT Penerbit IPB Press, 2014).

16. Beta, T., Nam, S., Dexter, J. E. \& Sapirstein, H. D. Phenolic content and antioxidant activity of pearled wheat and roller-milled fractions. Cereal Chem. 82, 390-393 (2005).

17. Nurhadi, B. \& Nurhasanah, S. Sifat Fisik Bahan Pangan. Bandung: Widya Padjajaran (2010).

18. Muchtadi, MS., Sugiyono, Ayustaningwarno, F. Ilmu Pengetahuan Bahan Pangan. (Penerbit Alfabeta, 2013).

19. Molyneux, P. The Use of the Stable Free Radical Diphenylpicryl-hydrazyl (DPPH) for Estimating Antioxidant Activity. Songklanakarin J. Sci. Technol. 26, 211-219 (2004).

20. Nayak, P. K., Dash, U., Rayaguru, K. \& Krishnan, K. R. Physio-Chemical Changes During Repeated Frying of Cooked Oil: A Review. J. Food Biochem. 40, 371-390 (2016).

21. Suryani, A., Hambali, E. \& Hidayat, E. Membuat aneka abon. Penebar Swadaya. Jakarta (2007).

22. Syamsir, E. et al. Penuntun Praktikum Teknologi Pengolahan Pangan. Bogor Dep. Ilmu dan Teknol. Pangan, Fak. Teknol. Pertanian, Inst. Pertan. Bogor (2011).

23. Alam, M. N., Bristi, N. J. \& Rafiquzzaman, M. Review on in vivo and in vitro methods evaluation of antioxidant activity. Saudi Pharm. J. 21, 143-152 (2013).

24. Aisyah, Y., Rasdiansyah, R. \& Muhaimin, M. Pengaruh pemanasan terhadap aktivitas antioksidan pada beberapa jenis sayuran. J. Teknol. dan Ind. Pertan. Indones. 6, (2014).

25. Agustine, E. S. Evaluasi Karakteristik Fisikokimiawi dan Sensoris Chicken Nugget Dengan Substitusi Tepung Bekatul. (2010). 